\title{
医楽品の微生物污染の動向
}

\author{
一 3 年前との 比較*1
}

紀氏沉恵, 片岡和三郎, 服部順一, 鈴木芳郎, 西井諭司, 佐藤健太郎, 藤井康子, 小野彪, 山路昭, 富松邦彦, 平岡喿一*2

大阪大学医学部付属病院薬郕部 $* 2$

\section{Evaluation of Microbial Contamination of Pharmaceutical Products*1}

\author{
Hiroe Kishi, Kazusaburo Kataoka, Junichi hatTori, Yoshio \\ SUzuki, Satoshi Nishil, Kentaro Sato, Yasuko FuJII, TaKeshi \\ ONO, AKIRA YAMAJI, KUNIHIKO TOMIMATSU and EIICHI HIRAOKA*2 \\ Department of Pharmacy, Osaka University Hospital*2
}

\begin{abstract}
Twenty one pharmaceutical products which had shown a positive reaction of microbial contamination in all of the 5 culture media in the previous sterility test were selected for this test. This paper compares the levels of microbial contamination in the latest test with those in the previous test conducted 3 years before, and also analyzes the tendency of the recent quality control of pharmaceutical products in relation to microbial contamination. In the latest study, total aerobic microbial count of more than $10000 / \mathrm{g}$ was observed in 3 of the 21 products, showing the same incidence as in the previous test. Total aerobic microbial count of less than $1,000 / \mathrm{g}$ was observed in 15 products, as compared to 10 in the previous test. Coliform organisms were detected in 2 products, compered to 6 in the preceding study.
\end{abstract}

\section{はじめに}

医薬品の品質管理上, 微生物污染は重要な試験項目の ひとつであると考えられる。しかし 3 年前に著者らが微 生物污染の検討 ${ }^{1,2)}$ を行なった時点では，無菌を必要と しないいわゆる非無菌製剤に関してなんら法的な規制は なかった. その後, 昭和 51 年 4 月 1 日付で厚生省から 薬発第 297 号3) が出され，内用液剤および X 線造影剂 の菌数の限度が示されたが，その他の剂形の無菌を必要 としない医薬品の微生物污染に関しては，未だなんら法 的な規制はない，一方，わが国においても GMP の実施 細則が昭和 51 年 4 月に実施され, 医薬品の原料および 製造工程ならびに保管の状態が，清潔かつ衛生的である

*1 本論文の要旨は日本薬学会第 97 年会 (果京, 1977 年4月）で発表

*2 大阪市福島区福岛 1 丁目 1-50;1-50，Fukushima 1-chome, Fukushima-ku, Osaka-shi, 553 Japan
ことが益々必要となってきた。 そこで再び，医薬品の微 生物污染度の検討を行ない, 3 年前の結果と比較するこ とにより，医薬品の品質が微生物污染の面よりみていか に改良されたかを考察した。

\section{実 臨 の 部}

\section{1. 操 作}

1）検液の調製

前回" に準じて行なった.すなわち，滅菌りン酸緩衝 食塩液 $100 \mathrm{ml}$ に, 錠剤またはカプセル刻の場合は 10 個, 散剤の場合は $10 \mathrm{~g}$ を溶解あるいは懸濁させて検液を調 製し,さらに, 隇菌リン酸緩衝食塩液を用いて検液を無 菌的に 10 倍希积しこれを 10 倍希积検液とした。

2）一般生菌数の測定

前回”に準じて平板混釈法で行なった。すなわち，検 液および 10 倍希釈検液各 $1 \mathrm{~m} \ell$ を, 各々 5 枚の隇菌ぺ トリー皿に分注したのち, 溶解させた市肘の SCDLP 寒 
天培地「ダイゴ」を注いでよく混合し，30〜32 2 で 3 日 間培養した。培養後, 出現したコロニーを計数して平均 し, 一般生菌数を求めた. 結果は錠剤あるいはカプセル 剤の場合は 1 個あたり, 散剤の場合は $1 \mathbf{g}$ あたりの生菌 数で示した.

\section{3) 無菌試験}

前回"に準じて行なった。すなわち，あらかじめ15ml の TGCLP 寒天培地を分注した試験管を各検液につい
て 6 本用意し， 1 本を対照用，他の 5 本を無菌試験判定 用とした. 各々の試験管に検液各 $1 \mathrm{~m} \ell$ を加え，上く混合 したのち, 30〜32 で 1 週間培盖した。培養後, 冷蔵庫に 保存した対照用と比較して各培養管の菌の增殖の有無を 判定し，培養管 5 本中の陽性管数で結果を示した。

4) 大腸菌群検出試験

薬発第 297 号》)に準じて行なった. 以上の全操作の概要を図 1 に示した.

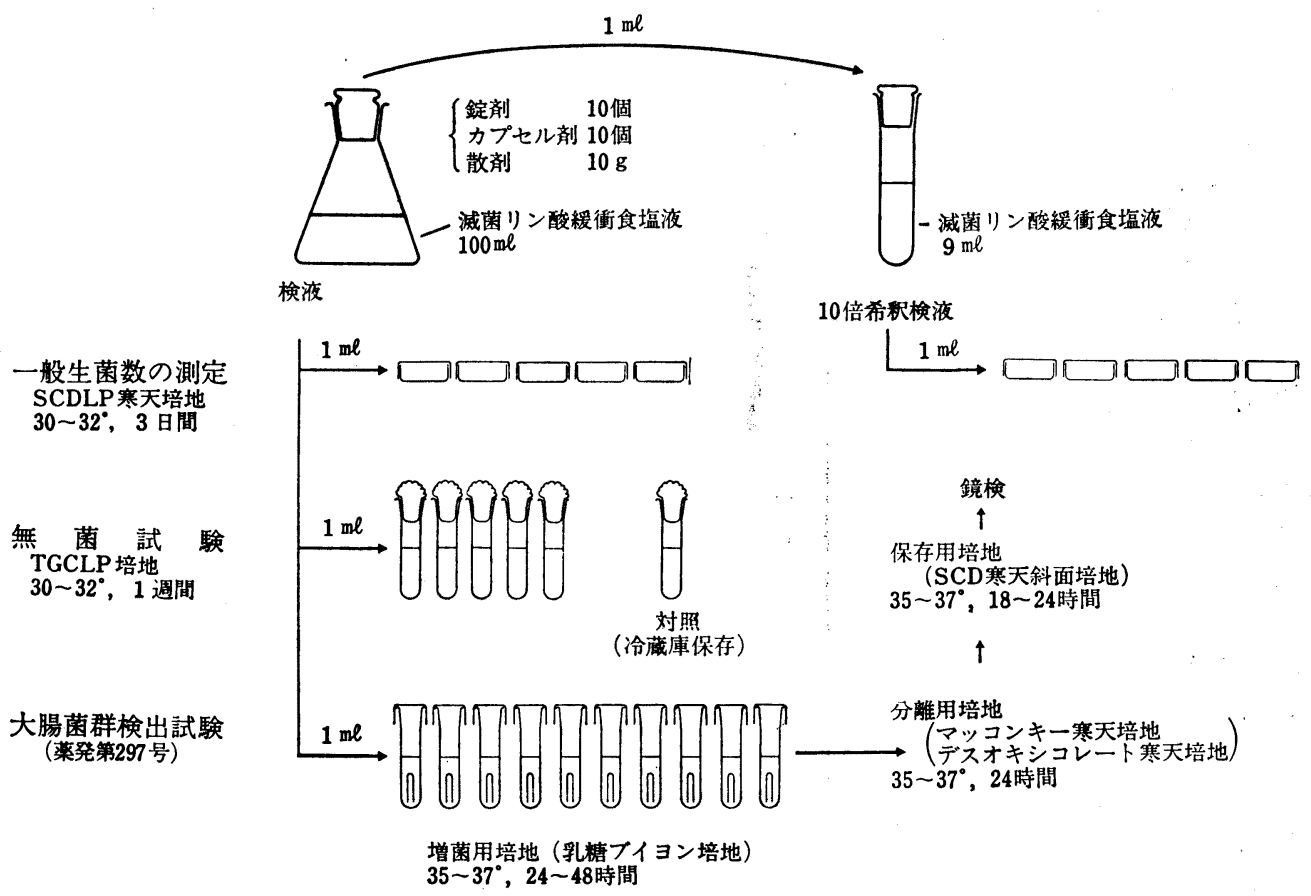

因 1. 実䤅操作の概要

\section{2. 実験に用いた医来品}

当院購入の医薬品について, 前回 ( 3 年前) 実験に用 いた 63 品目中, 表 1 に示した 22 品目が無菌試験の結 果培養管 5 本中 5 本陽性 (5/5) を示した ${ }^{11}$.この 22 品目 中, トロンボゲンは現在製造中止であるため,これを除 く21 品目について今回再び実験を行なった.

\section{実験桔果および考察}

前回 ( 3 年前) の実験の結果, 無菌試験の結果と一般 生菌数との間には, 図 2 に示すように, ある一定の菌数 の幅をもちながら相関のみられることがわかっだ1) そ こでこの関俰から，図3に示すような比較的簡易な微生 物污染試験法を提案した。すなわち，検液各 $1 \mathrm{ml}$ を用
いてまず 5 本の無菌試験を行ない，その結果，培養管 5 本中の陽性管数が 2 本 $(2 / 5)$ 以下であれば一般生菌数 は $10^{2}$ 以下, 培養管 5 本中の陽性管数が 4 本 (4/5) 以 下であれば一般生菌数は $10^{3}$ 以下と判定すれば良いと 考元た，そして，医薬品の一般生菌数の許容限度を $10^{3}$ と仮定した場合には，培養管 5 本中 5 本陽性 (5/5) を示 す医薬品の及が $10^{3}$ 以上の一般生菌数を示す可能 性が あるために，この $5 / 5$ の場合のみ菌数測定を行なえば良 いと考六, 図 3 に示すような提案を行なった。 3 年後に 行なった今回の実験においても，図 2 および図 3 に示す ような関係が矛盾なく成立するかどらかを検討すること も，今回あわせて行なった。

今回の実験による測定結果を表 2 に示した．比較のた 


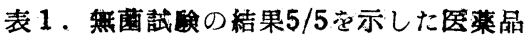
の一般生菌数

\begin{tabular}{|c|c|c|c|}
\hline 医 薬 品名 & 绪形 & ロット番咅 & 一般生菌数 ${ }^{11}$ \\
\hline マスチゲン & 散 & Z009S & $7.1 \times 10^{4}$ \\
\hline トロムボゲン末 & $"$ & 4510YHATO & $7.1 \times 10^{4}$ \\
\hline ゲンチアナ末 & $" \prime$ & $\mathrm{H} 74694$ & $3.6 \times 10^{4}$ \\
\hline チ ラーヂン & $n$ & DL7E2 & $2.0 \times 10^{4}$ \\
\hline ダイオウ 来 & $" \prime$ & TYAKAKタイ & $8.7 \times 10^{3}$ \\
\hline チ ラーヂン & $"$ & DL7E2 & $8.4 \times 10^{3}$ \\
\hline ゲシチアナ末 & $"$ & H74694 & $7.6 \times 10^{3}$ \\
\hline チ ラーヂン & $"$ & DL7E2 & $7.2 \times 10^{3}$ \\
\hline セン $ン$ 末 & $"$ & TMAARセナ & $5.8 \times 10^{3}$ \\
\hline エビオオ ス & $\prime \prime$ & ケFO & $5.0 \times 10^{3}$ \\
\hline ロートエキス散 & $"$ & H 29821 & $4.2 \times 10^{3}$ \\
\hline 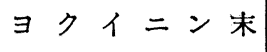 & ' & TYAAKT $\exists 7$ & $4.2 \times 10^{3}$ \\
\hline ジアスターゼ & $" \prime$ & 422YRON & $3.3 \times 10^{3}$ \\
\hline 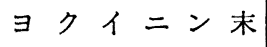 & $"$ & TYRKW $\exists 7$ & $3.1 \times 10^{3}$ \\
\hline エ ビ オ ス & $" \prime$ & ケFO & $3.0 \times 10^{3}$ \\
\hline 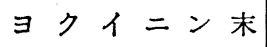 & $"$ & TYAAKT $\exists 7$ & $2.7 \times 10^{3}$ \\
\hline エビ オ & $"$ & ケFO & $2.6 \times 10^{3}$ \\
\hline タンニン酸アルブミン & $" \prime$ & 307YBAM & $1.3 \times 10^{3}$ \\
\hline アスパラ $\mathrm{M}$ & 錠 & WN69004T & $1.2 \times 10^{3}$ \\
\hline オラドールトローチ & $"$ & $30350 \mathrm{~A}$ & $5.0 \times 10^{2}$ \\
\hline ロートエキス散 & 散 & H29821 & $3.6 \times 10^{2}$ \\
\hline パンクレアチン & $"$ & 353YYKB & $2.9 \times 10^{2}$ \\
\hline エンドキサン & 錠 & E520W & $2.3 \times 10^{2}$ \\
\hline$"$ & $n$ & $" \prime$ & $1.9 \times 10^{2}$ \\
\hline マスチゲン $\mathrm{B}_{12}$ & $"$ & IO15S & $1.4 \times 10^{2}$ \\
\hline エンドキサン & $" \prime$ & E330L & $1.0 \times 10^{2}$ \\
\hline トウモロコシデンプン & 散 & 334 YOKR & $1.0 \times 10^{2}$ \\
\hline アドソルビン & $"$ & M671 & $7.6 \times 10$ \\
\hline ホミカエキス散 & $" \prime$ & $315 Y Y K N$ & $6.6 \times 10$ \\
\hline エンドキサン & 錠 & E530W & $6.0 \times 10$ \\
\hline ホミカエキス散 & 散 & $315 Y Y K N$ & $5.0 \times 10$ \\
\hline " & $"$ & $"$ & $4.2 \times 10$ \\
\hline パンカ ル G & $n$ & $6285 \mathrm{SHW}$ & $3.6 \times 10$ \\
\hline アデロキザール散10\%散 & $"$ & 5006 & $3.2 \times 10$ \\
\hline ノイロビタン & 錠 & 2380YNAAO & $3.0 \times 10$ \\
\hline
\end{tabular}

1）散戍の場合は $1 \mathrm{~g}$ あたり，錠棛の場合は 1 錠あたりの 一般生菌数を示す

めに，3年前の測定結果もあわせて示した。無菌試験の 結果 $5 / 5$ を示す医菓品は, 3 年前の 21 品目に対して 今回は 16 品目であり, 無菌試験の結果 $4 / 5$ を示す医 薬品は 21 品目中 2 品目, $3 / 5$ は 1 品目, 175 は 2 品目 であった。無菌試験の結果と一般生菌数の関係性，3年

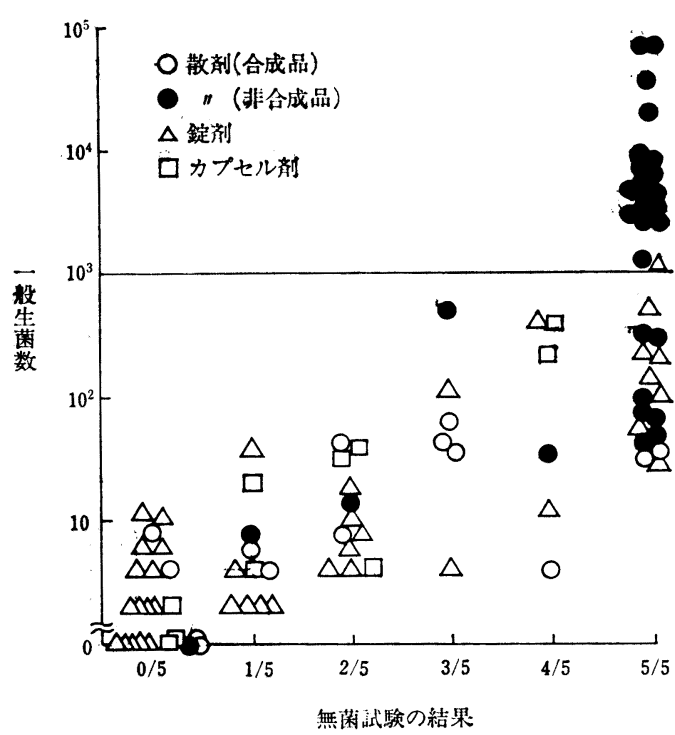

図 2. 無菌武験の結果と一般生菌数の関係

前と同様に，培養管 5 本中の陽性管数が 4 本以下の場合 は一般生菌数は $10^{3}$ 以下であり，培養管 5 本中の陽性 管数が 2 本以下の場合は一般生菌数は $10^{2}$ 以下であっ た。 そして $10^{3}$ 以上の一般生菌数は, 無菌試験の結果 $5 / 5$ を示す医薬品にのみみられた，3 年前と同様に，今回も 非合成医薬品，特に生薬製剤の污染の大きいことが涊め られた. 大腸菌群は今回も 2 品目の医薬品に検出され， それらは生薬製戍であった。

医萝品の微生物污染度を 3 年前と現在とで比較して表 3 にまとめた。医薬品の一般生菌数の許容限度を $10^{3}$ と 仮定した場合，この $10^{3}$ 以上の一般生菌数を示す医薬品 が問題となる. 3 年前は $10^{4}$ 以上の一般生菌数を示す 3 品目と $10^{3} \sim 10^{4}$ の生菌数を示す 8 品目の計 11 品目であ ったのに対して，今回は各々 3 品目計 6 品目であり，問 題となる医薬品の品目数としては減少していた.しかし, $10^{4}$ 以上の一般生菌数を示可䒨楽品が, 今回も 3 年前も ともに 3 品目もあり, さらに大腸菌群が今回も 2 品目に 検出された。これらのことより，微生物污染の面よりみ た医薬品の品質は，改良の方向にあるとは考えられる が, 質的変化は認められなかった。

一方, 内用液剤およびX線造影剤に関しては，薬発第 297 号 $^{3)}$ において「細菌は $1 \mathrm{mlまたは} 1 \mathrm{~g}$ あたり $1 \times 10^{3}$ 以下でなければならない」「大腸菌群は検出してはなら ない」と規定されている.内用液剤およびX線造影剂以 外の剂形の無菌を必要としない医菜品に対しても，微生 物污染に開する規定の設けられることが必要であると考 えられる。 
表 2. 医薬品の微生物污染の動向

\begin{tabular}{|c|c|c|c|c|c|c|c|}
\hline \multirow{2}{*}{ 医 薬 品 名 } & \multirow{2}{*}{$\begin{array}{l}\text { 剤 } \\
\text { 形 }\end{array}$} & \multicolumn{3}{|c|}{ 在（1976年10月） } & \multicolumn{3}{|c|}{3 年 前 （1973年11月） } \\
\hline & & ロット番号 & $\begin{array}{l}\text { 無菌試験 } \\
\text { 結 果 }\end{array}$ & 一般生菌数 ${ }^{1)}$ & ロット番号 & \begin{tabular}{|l} 
無菌試䮤 \\
結 果
\end{tabular} & 一般生菌数 ${ }^{11}$ \\
\hline マスチゲン & 散 & A6M004 & $5 / 5$ & $5.7 \times 10^{4}$ & $\mathrm{Z}^{0} 09 \mathrm{~S}^{2)}$ & $5 / 5$ & $7.1 \times 10^{4}$ \\
\hline 七ン & " & ANSAセ & " & $4.5 \times 10^{4}$ & TMAARセた2) & $"$ & $5.8 \times 10^{3}$ \\
\hline ゲンチアナ米 & $"$ & WAWM ケチ 1 & $"$ & $1.5 \times 10^{4}$ & $\mathrm{H} 74694$ & $"$ & $3.6 \times 10^{4}$ \\
\hline チラーヂン & $"$ & HE14DH19A & $" \prime$ & $7.4 \times 10^{3}$ & DL7E2 $2^{2)}$ & $"$ & $2.0 \times 10^{4}$ \\
\hline 多オウ末 & $"$ & ATKMタイ1 & $"$ & $2.2 \times 10^{3}$ & TYAKAK夕イ & $\prime \prime$ & $8.7 \times 10^{3}$ \\
\hline ジアスターゼ & $"$ & 0380QOS & $"$ & $1.6 \times 10^{3}$ & $422 \mathrm{YRON}$ & $" \prime$ & $3.3 \times 10^{3}$ \\
\hline パンクレアチン & $"$ & 106ASAN & $"$ & $8.9 \times 10^{2}$ & $353 Y_{Y K B^{2)}}$ & " & $2.9 \times 10^{2}$ \\
\hline$\exists ク イ$ ク 末 & $"$ & $\operatorname{AMSA} \exists ク 1^{2)}$ & $" \prime$ & $5.5 \times 10^{2}$ & TYAAKT $\exists ク^{2)}$ & $"$ & $4.2 \times 10^{3}$ \\
\hline エ ビオ オ & $"$ & $62 \mathrm{HH}$ & $"$ & $3.7 \times 10^{2}$ & ケ $\mathrm{FO}^{2)}$ & $"$ & $5.0 \times 10^{3}$ \\
\hline ロートエキス散 & $"$ & S74614 & $"$ & $3.4 \times 10^{2}$ & H29821 & $\prime \prime$ & $4.2 \times 10^{3}$ \\
\hline タンニン酸アルブミン & $"$ & 082AHOR & $"$ & $1.8 \times 10^{2}$ & 307YBAM & $"$ & $1.3 \times 10^{3}$ \\
\hline ホミカエキス散 & $"$ & $0260 \mathrm{HKN}$ & $\prime \prime$ & $1.5 \times 10^{2}$ & $315 Y Y K N$ & $"$ & $6.6 \times 10$ \\
\hline トウモロコシデンプン & $"$ & 045AMAH & $\prime \prime$ & $1.0 \times 10^{2}$ & 334 YOKR & $\prime \prime$ & $1.0 \times 10^{2}$ \\
\hline アデロキザール10\%散 & $"$ & 9017 & $"$ & $9.0 \times 10$ & 5006 & $"$ & $3.2 \times 10$ \\
\hline アドソルビン & $"$ & N943 & $"$ & $2.8 \times 10$ & M671 & $"$ & $7.6 \times 10$ \\
\hline オラドールトローチ & 錠 & $60110 \mathrm{E}$ & $"$ & $2.4 \times 10$ & $30350 \mathrm{~A}$ & $"$ & $5.0 \times 10^{2}$ \\
\hline エンドキサン & $"$ & A320R & $4 / 5$ & $1.4 \times 10^{2}$ & E520W & " & $2.3 \times 10^{2}$ \\
\hline パンカ ル G & 散 & $6447 \mathrm{SGZ}$ & $"$ & $1.6 \times 10$ & $6285 \mathrm{SHW}$ & $" \prime$ & $3.6 \times 10$ \\
\hline マスチゲン $\mathrm{B}_{12}$ & 錠 & A4M011 & $3 / 5$ & $9.0 \times 10$ & I015S & $"$ & $1.4 \times 10^{2}$ \\
\hline アスパラ $\mathrm{M}$ & $"$ & 66 亿21 & $1 / 5$ & $1.2 \times 10$ & WN69004T & $"$ & $1.2 \times 10^{3}$ \\
\hline ノイロビタン & $"$ & $7750 \mathrm{P}$ & $"$ & 0 & 2380YNAAO & $\prime \prime$ & $3.0 \times 10$ \\
\hline
\end{tabular}

1）散剂の場合は $1 \mathrm{~g}$ あたり，錠剤の場公は 1 錠あたりの一般生菌数を示す 2$)$ 大腸菌群が検出された 医薬品 $10 \mathrm{~g}$
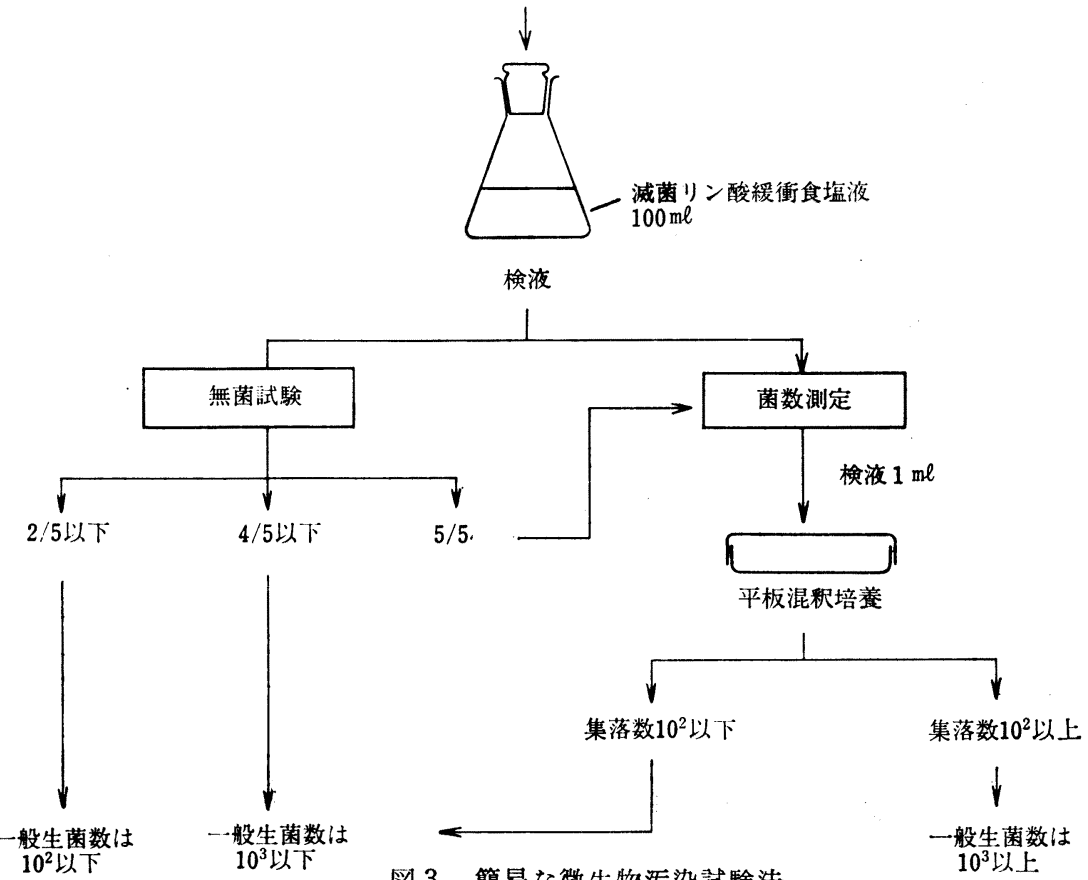

困3，簡易な微生物污染試験法 
表 3 . 医薬品の微生物污染度の比較

\begin{tabular}{|c|c|c|}
\hline \multirow{2}{*}{ 一般生菌数 } & 品 & 数 \\
\hline & 現在(1976年10月) & 3 年前(1973年11月) \\
\hline$>10^{4}$ & $3(1)$ & $3(2)$ \\
\hline $10^{3} \sim 10^{4}$ & 3 & $8(3)$ \\
\hline$<10^{3}$ & $15(1)$ & 10 (1) \\
\hline 合＼cjkstart計 & 21 (2) & 21 (6) \\
\hline
\end{tabular}

（）内は大腸菌群の検出された品目数を示す
文献

1) 紀氏汎恵, 小野彪, 森元君子, 本多一成, 沢, 井政美, 伊佐幸雄, 平岡栄一, 米虫節夫, 城倉り亲 子, 三浦喜温: 薬剤学, 36, (1), 38 (1976).

2) 米虫節夫, 城倉りき子, 三浦喜温, 本多一成, 小 野彪, 森元君子, 紀氏汎恵, 平岡栄一: 薬剤学, 37, (1), 28 (1977).

3）厚生省薬務局長：薬発第 297 号, 内用液剂及び $\mathrm{X}$ 線造影剤の菌数の限度及び試験法について（1976年 4 月 1 日).

\section{定員 110,000 !}

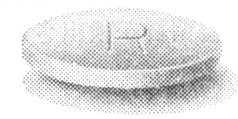

解熱鎮痛消炎剂

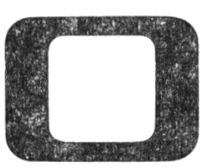

ごらんくださいいロナールは一見何の变哲もない錠剤ですが、 この中には11ラ個のアスピリン・マイフロカプセルが入れてあ りま。

ロナールはこのように目細かく仕上げられていますが、こ れは雪障害軽減と吸収の问上を狚つた新らしい試みです。
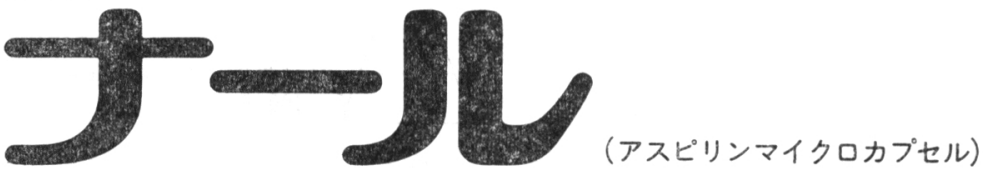

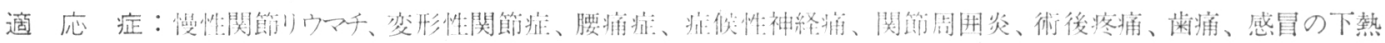
用法・用量

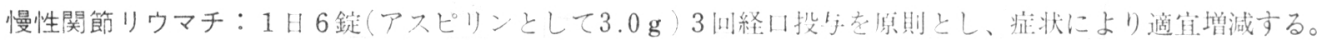

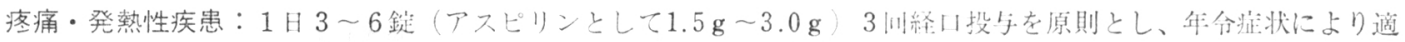
査增娍军る。

歯科・ 日腔外科領域の疼痛には： 1 回 $2 \sim 4$ 鉸(アスピリンとして $1.0 \mathrm{~g} \sim 2.0 \mathrm{~g}$ ) を頓用守る。

薬価：1鋜当り 9.00 円

識別コード：TO-104(PTP 10 P シート赛面に印刷)

使用上の注意については製品添付の説明書をよくお読み下さい。 